\title{
Challenges and Opportunities for Improving Growth in the Information Technology Services Sector in Romania
}

\author{
Raluca Robu \\ Department of International Economics and Business \\ Bucharest University of Economic Studies \\ Piata Romana, nr. 6, sector 1, Bucharest, Romania \\ Alina-Petronela Alexoaei \\ Department of International Economics and Business \\ Bucharest University of Economic Studies \\ Piata Romana, nr. 6, sector 1, Bucharest, Romania
}

\begin{abstract}
The main purpose of the paper is to analyze the information and communication technology sector in Romania and its export competitiveness in relation to two types of company strategies and actual trends identified by consultancy firms: reducing operating costs and obtaining cost efficiency. We find a positive evolution of the ICT sector (exports' growth and increased labor specialization in ICT), but a substantial difference between Romania and the regional leaders. To describe cost efficiency, we choose labor productivity as an indicator, which generally decreased in the region, given the labor cost growth. In the last part of the analysis, running a panel data regression, we aim at identifying how the factors, which are mostly targeted in the company strategies, labor cost and labor productivity, have a higher impact on the export growth in ICT in the European Union. Our findings suggests that companies should focus more on increasing productivity rather than reducing costs.
\end{abstract}

Keywords: information technology services, export competitiveness, labor productivity, labor cost.

\section{Introduction}

Romania's geographic position in Europe brings numerous advantages for improving its position as a "nearshore" location for Western European outsourcing in the information technology sector due to its relative physical proximity, close time zone and cultural similarities. Nevertheless, Romania has to compete to other Central and Eastern European countries, which have also advanced in fructifying their competitive advantages.

This paper proposes an analysis of the evolution of the information technology sector at country level and a comparison to the neighboring EU countries. Following the results identified in the empirical literature, which places labor skills and costs in the central preoccupations of companies, we describe the evolution of employment in the ICT sector in Romania. The purpose is to see the regional position of Romania as an IT nearshore location and the potential and challenges associated to the regional attractiveness of Romania. Given the fact that the investors are originating from Western European countries or the USA, the Eastern European countries are very suitable locations given the size and quality of the labor pool. All these host countries are aware of the development potential of their ICT sector and put consistent efforts into offering advantages for the investors, foreign or domestic, and improving their exports as well.

To describe the IT service sector in Romania, we use descriptive statistics of market volumes, exports and foreign direct investments. Additionally, data referring to labor market and education capture the limits of development potential (determined by the number of people that are and can be qualified to provide this type of services), in the same time, seeing the availability of qualified workforce as the main regional attractiveness factor for ICT investments.

Given the extended empirical literature, we analyze labor market as a main investment attractiveness factor comparing two types of company strategies and actual trends identified by consultancy firms: reducing operating costs and obtaining cost efficiency. Regarding the operating costs, we focus on the labor costs. We notice an increase in the labor costs in all Eastern European, while Romania stays among the cheapest locations. To describe cost efficiency, we choose labor productivity as an indicator, which generally decreased in the region, given the labor cost growth. We choose labor and productivity to be two of the most important criteria for investments and test their impact on the export performance, by running a panel data regression for the ICT sector in the European Union. Since, the Romanian internal market is small and Romania is rather a provider of outsourcing services, the export performance would confirm a good decision of choosing this investment location. 
The panel includes almost all EU member states because we try to identify what kind of investments, in the ICT sector, would potentially export more domestically created value added: those that manage to reduce labor costs or those that increase labor productivity. Our findings suggest that companies should focus more on increasing productivity rather than reducing costs.

Since Romania's IT market is dominated by multinational companies which offer mostly basic IT services, it leaves opportunities for local entrepreneurs to develop high value-added services and to increase labor skills in order to attract foreign investments both in the form of captive centers and outsourcing companies.

After we review the related literature, in the following sections we describe the current development stage of the ITC sector in Romania, the recent trend and a brief comparison to other EU countries. Then, we introduce the issue of labor cost and labor productivity as determinants of export competitiveness and finally the test the impact of these determinants on a panel of European Union member states.

\section{Literature review}

Specialization in the information technology and communication services sector brings new opportunities for specialization as demand for new and efficient technical solutions is increasing in any area of activity. This sector's development has, as a positive effect, the easier access of companies, institutions and people to advanced technology and specialized information and communication technologies (ICT) services when performing in an ICT agglomeration.

In this context, a broad part of the literature has focused on the impact that digitization has on the overall firm productivity. Several authors find positive effects of ICT use and development of productivity at firm, industry and macroeconomic level (Draca, et. al., 2006; Sharpe, 2006). In the same time, notable differences in productivity appeared between the USA and Europe under the impact of ICT development. Bart van Ark et. al. (2003, pp. 295) find that the main drive for the faster growing US productivity is "a larger employment share in the ICT producing sector and faster productivity growth in services industries that make intensive use of ICT". Later, the growth rhythm of the productive effects of ICT was reduced because of a lower territorial diffusion of this activity especially in developed countries, other than the USA: European countries and Japan (Cette, et. al. 2015). Barriers to the spread of ICT investments in these countries reside in institutional issues, such as: "a lower education level, on average, of the working-age population and more regulations on labor and product markets" (Cette, 2014, pp. 473). For some countries, digitization in both the private and public sector represents an opportunity for overpassing development barriers and reducing the lag against other countries. The case of Romania is extensively treated by McKinsey \& Company (2018).

Developing the ICT sector and improving digitization based on services which are locally provided requires local investments. Since the paper attempts to identify the challenges and opportunities for improving growth in the Information technology services sector in Romania, we must first find the factors that attract investments in a certain area.

Quality, qualification, cost and availability of labor force alongside with innovation and reliable ICT infrastructure are the main drivers for localization of ICT services and business services as most authors conclude (Meliciani and Savona, 2014; Barrios, et. al. 2008, Miranda Levy, C., 2007).

A key issue regarding the attractiveness of ICT investments is the regional dispersion of ICT service activity because territorial concentration leaves unexploited potential in regions where they spread less and which have less access to technology, fewer opportunities to increase productivity and incomes. However, the trend is rather an agglomeration of ICT service companies, as literature reveals.

The spatial dispersion of ICT localization is determined by two types of forces. First, there are centripetal forces that lead to concentration (Lasagni and Sforzi, 2007). Decentralization of technology intensive activities enrolls in a strategy of following the locations that offer knowledge and techniques at a superior level (Acemoglu et al., 2006). That implies not only the fact that agglomerations host qualified workforce but also intensive innovation and spillover opportunities. Kox and Rubalcaba (2007) support the idea that business services locate in large cities to find qualified labor. The argument seems as relevant for IT services.

The second type of forces that determine the localization of ICT activities are centrifugal forces, which appear because technology diminishes the need for physical proximity to the other functions of the company, customers and suppliers (Lasagni and Sforzi, 2007). The ICT activities are among the easiest services to outsource offshore and the ICT intensive companies are more likely to move certain functions abroad and to external providers because technology itself reduces transactions costs (Abramovsky and Griffith, 2006). The two forces, acting simultaneously, lead to the delocalization of ICT activities and towards specialized locations and concentration. 
Investments in the ICT sector in Romania can be seen either as a result of centripetal forces because there is a concentration of activities in large urban areas with skilled labor and of centrifugal forces as well because the markets served by the companies in this industry are mostly located in other countries.

Attractiveness factors coincide to what is known as competitiveness factors because investors choose to locate their activities where maximum benefits can be obtained and, therefore, where they can be competitive. Because in this paper we choose to focus on two of the most important factors for competitiveness, labor cost and productivity, we briefly summarize some ideas that support them in the literature. Relatively cheap labor has always been said to attract investments in Eastern European countries and in Romania as well. Labor cost resides among the factors for competitiveness starting with Porter (1990) and Dunning \& Lundan (1993) lists labor costs among location determinants in the OLI paradigm. Productivity is in a direct relationship with labor cost. In countries where labor is more expensive, productivity is higher as well (Abraham, 2001) because wages cannot be increased unless employees become more efficient and provide more value added. Apart from productivity, there are other factors influencing labor costs, which mainly shape demand and supply. This is why labor cost elasticity to productivity differs from one country to another (Abraham, 2001) and in some countries like Russia (Kapeliushnikov, 2014) and Romania wages increase faster than productivity.

The competitiveness of a certain economic sector can be measured by the level of exports that it generates. It is a recognition of the fact that the provided services or products are not only suitable for national consumers, but also for the international markets. The relationship between export competitiveness on one side and labor cost and productivity on the other side has been tackled in the literature so far. Mbaye (2002) perform an analysis for manufactured products exported by African countries and find a significant determination of unit labor cost decrease over the export competitiveness. Guerrieri \& Meliciani (2004) also identified a negative impact of labor costs on international specialization and competitiveness. Guan \& Ma (2003) find a positive correlation between productivity and export competitiveness. Saripalle (2007) confirms the comparative advantage constituted by low wages, but he's analysis reveals that what ultimately matters for export competitiveness is the productivity related to labor costs.

\section{The evolution of the information technology sector in Romania}

National Bank of Romania provides statistical data for Romania's foreign trade including information and telecommunication services in a single category.

The evolution of exports and imports in the services of information and telecommunication is positive. Except for a short period in December 2013, Romania was a net exporter for this type of services and the difference between exports and imports increased from 175 million euros in March 2013 to 574 million euros in May 2019. The export in 2013 was of 416 million euros and it reached 1226 million euros in 2019. The turnover index $(2015=100)$ of the companies in Information service activities (Eurostat), in the same period, had a slight increase as well. It suggests that the turnover growth is more based on the exports as a result of increased demand on the external markets in general or based on the increased export competitiveness of Romania. Because the imports grew as well, there are possible differences in the type of services consumed on the internal market compared to those exported.

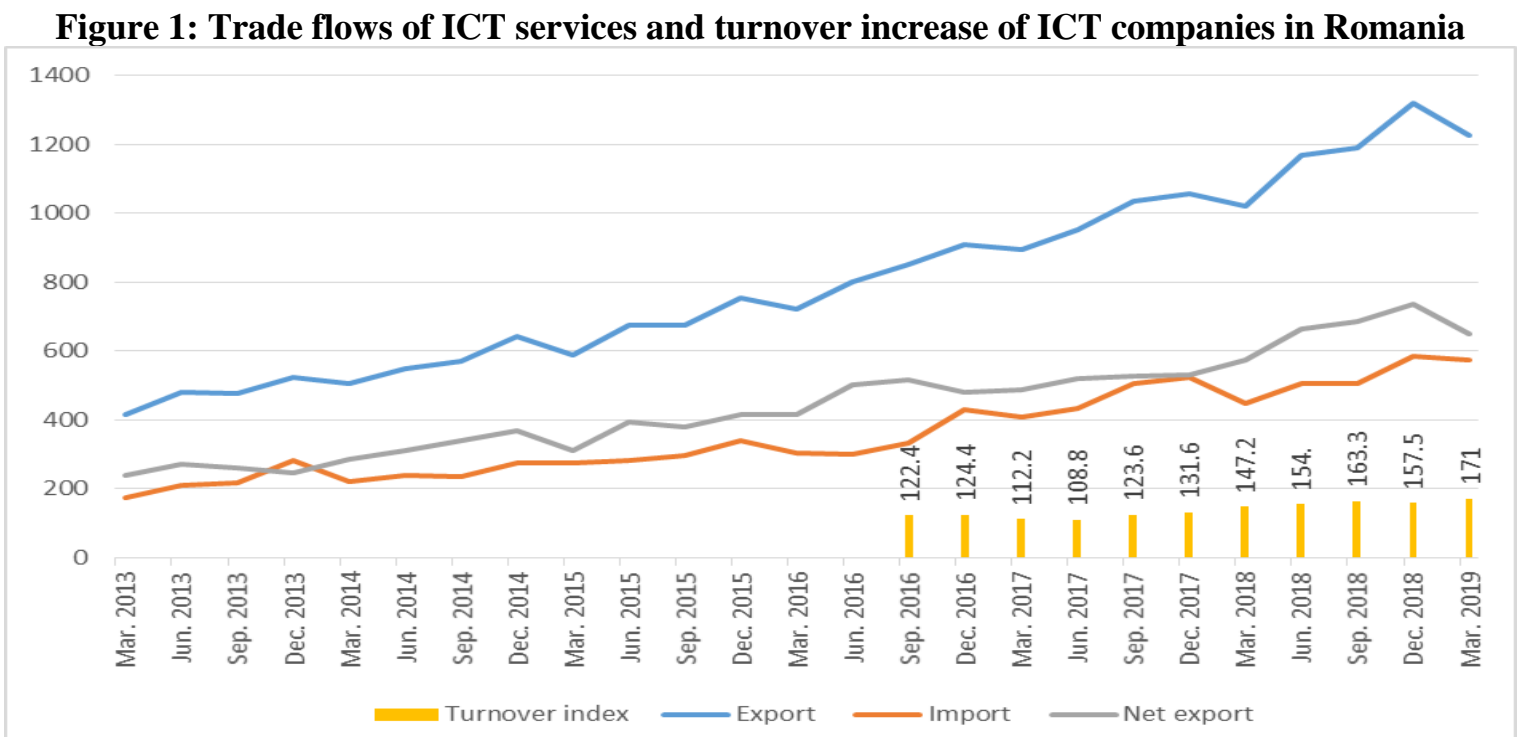

Source: compiled by the authors based on data from the National Bank of Romania and Eurostat 
Foreign direct investments stock in the ICT sector in Romania experienced a decrease in 2016 and 2017 comparing to the previous years. The FDI decreasing trend signals possible problems or uncertainties regarding the investment climate in Romania in general, not only in ICT. This evolution overlapped to a rather continuous increase of exports of ICT services. In 2017 the contribution of companies with Romanian capital to the exports of ICT services increased, reaching almost the same percentage in 2014, after we had experienced a two year increase of the export contribution of companies with foreign capital. However, the Romanian exports of ICT services are still mainly supported through foreign direct investments, while the FDI is currently being redirected towards other sectors as shown by the share of ICT FDI in the total FDI stock.

Table 1: Foreign Direct Investments in ICT in Romania (Million euros)

\begin{tabular}{|l|l|l|l|l|}
\hline & $\begin{array}{l}\text { FDI Stock in ICT } \\
\text { Yervices }\end{array}$ & $\begin{array}{l}\text { The share of ICT } \\
\text { FDI in the total FDI } \\
\text { stock }\end{array}$ & $\begin{array}{l}\text { Export share of FDI } \\
\text { companies in the } \\
\text { The Exports of FDI } \\
\text { companies in ICT } \\
\text { sector }\end{array}$ \\
\hline 2010 & 3081 & $5.90 \%$ & & \\
\hline 2011 & 2967 & $5.40 \%$ & & \\
\hline 2012 & 2854 & $4.80 \%$ & & \\
\hline 2013 & 4129 & $6.90 \%$ & & \\
\hline 2014 & 3598 & $6.00 \%$ & 1719 & $75.80 \%$ \\
\hline 2015 & 3690 & $5.70 \%$ & 2110 & $78.40 \%$ \\
\hline 2016 & 3628 & $5.20 \%$ & 2635 & $80.40 \%$ \\
\hline 2017 & 3150 & $4.10 \%$ & 2981 & $75.70 \%$ \\
\hline
\end{tabular}

Source: National Bank of Romania, 2017

\section{Labor market in ICT services in Romania. Competitiveness/attractiveness based on reduced costs or increased skills?}

We calculated the share of employees in Information and Communication in the total number of employees in each country to show the evolution of specialization in this sector (data collected from Eurostat). We selected only the employees aged between 25 and 64 years old.

Figure 2: The share of employees in information technology services in the total number of employees

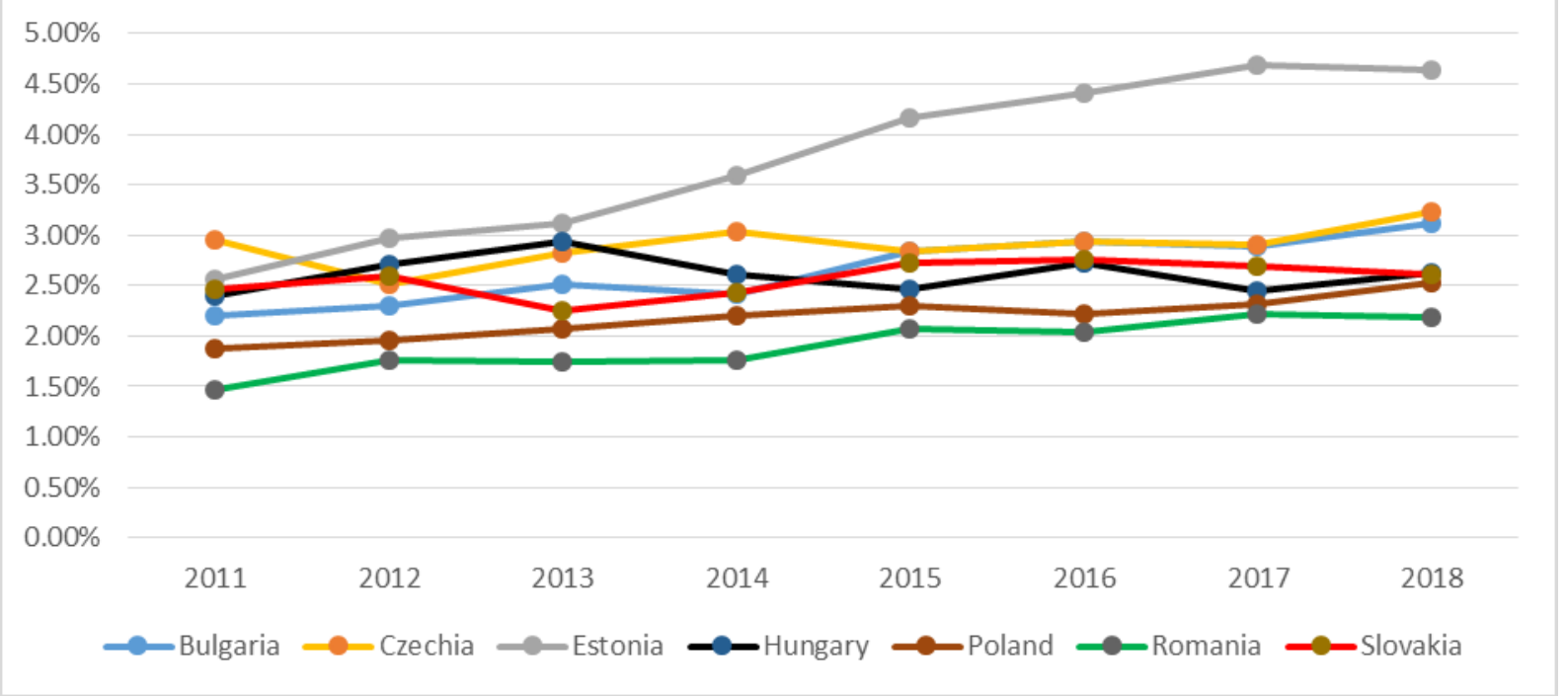

Source: compiled by the authors based on data from Eurostat

We notice, that among the selected Central and Eastern European countries, Romania is the least specialized in the information and communication sector, although it had an overall increase in the analyzed period. The most rapid evolution belongs to Estonia, which became the country with the highest share of information technology employment after 2012, surpassing the Czech Republic which was the leader in 2011. This data shows the improvement potential in the development of this sector in Romania, which can be expanded by an increase in the labor force specialization (with corresponding education). 
The Romanian National Institute of Statistics shows a decrease in the number of students enrolled in B.A. programs in information technology and communications from 27034 (2014) to 25631 (2015), while in 2017 it increased to 28815. In master's programs there was a decrease from 7208 students in 2014 to 6523 in 2015, than the number grew to 7098. In the same time there was a decrease in total number of students probably based on the lower graduation rate of baccalaureate and lower quality of high school education, increased emigration, etc. However, the demand for tertiary education in the ICT area is not correlated to the increasing demand in the labor market. The policies which aim at developing the ICT sector need to increase the number of specialists (by growing the number of students), the labor force pool being one of the first conditions to attract investments. The increase in the number of students in ICT in the latest year is a positive result of the sustained fiscal incentives offered to the employees in ICT and the relatively higher wages in this sector. However, the labor supply in ICT still does not meet the demand, the managers, instead of focusing of externalizing ICT services as a solution for the lack of personnel, focus more on digitalizing and automatizing more processes (Harvey Nash and KPMG, 2018). Since the economic and political environment is still unstable, the policies which influence the labor market and investments in the ICT sector are either changing or unreliable. However the Government Ordinance no. 7/2001, which decides a tax exemption for labor incomes obtained from software development, has been in place since 2001.

Since labor is one of the most important factors of attractiveness for ICT investments, the challenge is to establish the right balance between labor qualification and costs for all parts involved: the ICT service providers and policy makers. KPMG (2014) study was emphasizing that clients' demands for ICT services were diversifying, putting more pressure on spurring the service quality. The study displayed several old and new demands of clients of business services, in general. In the past, the focus used to be on: reducing operating costs, improving process performance and economies of scale and now the shift is on: innovation, differentiation, cost efficiency and process re-engineering. So cost reduction is important, but in a way that does not sacrifice the service quality, on the contrary based on increased efficiency. That is conditioned by the skills of the workforce.

The 2018 ANIS study indicates an increase in the productivity of labor in software and IT services in Romania from 43140 euros per employee in 2016 to 44519 euros per employee in 2017.

Still, comparing to the other countries in Central and Eastern Europe, the labor cost in Romania is low, but also the availability of IT specialists is relatively low having a relatively lower number of skills (ANIS, 2016). However, Romania hosts an important labor pool in capital city Bucharest and in Cluj-Napoca city, which has experienced a very rapid development of the ICT sector in the past years. For Cluj-Napoca, the competitive university center, financial center, qualified personnel with wide language skills and growing number of local firms are creating a pool which is able to provide research and software development. The same study exhibits what constitutes the specialization on services provided by companies operating in Romania: low-end support services, coding and application management, rather than high added-value software product development or critical IT services. The same idea is supported by Grigoraș et al. (2017) who also sustain that a shift from the current specialization on implementing and working with existent technologies and outsourcing to supplying information solutions would stimulate the development of this sector in Romania. The present market positioning does not stimulate labor qualification and innovation and limits the benefits of specialization in information technology services. Usually, companies which compete on this niche are forced to reduce costs, although salaries, in this sector, are placed on a growing trend, this pressure limits wages increase and economic development. ANIS (2018) also points out that the market belongs merely to big companies. A concomitant increasing demand in Western Europe for high-value added services leaves opportunities for local entrepreneurs.

Figure 3: Labor cost evolution (Average personnel costs per employee) - thousand euros

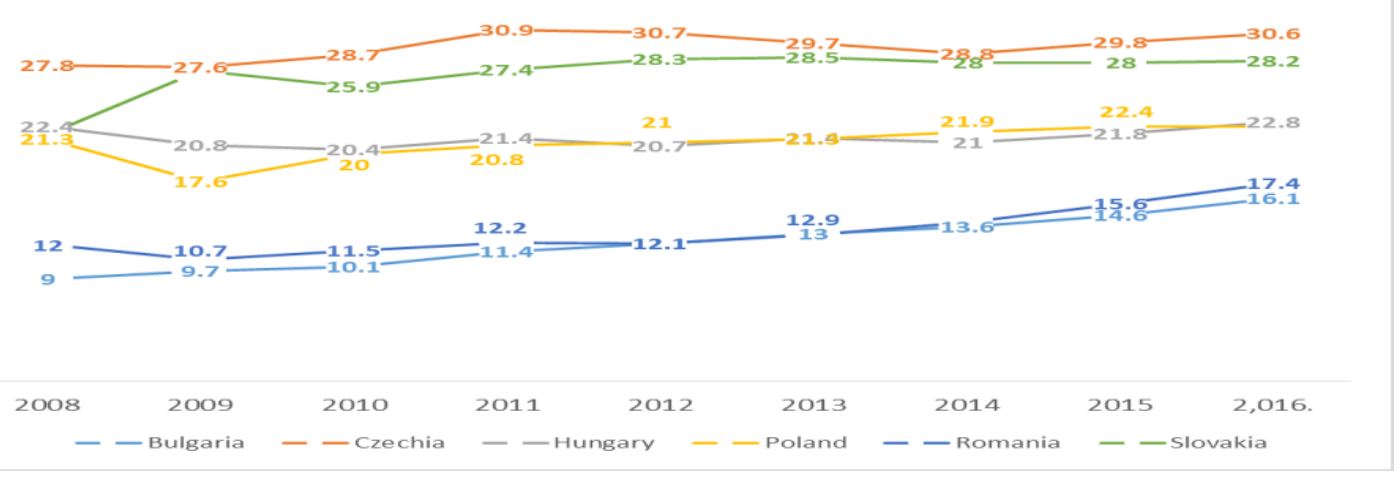

Source: compiled by the authors based on data from Eurostat 
The analysis cost reduction vs. cost efficiency is very important for companies that establish to go offshore with IT services but must decide between captive centers (service centers owned by the company) and outsourcing (external providers). Worldwide, the role of captive offshore operations centers is increasing and evolving to more sophisticated skills and capabilities in guiding managers to make better decisions due to higher expertise in business services, research and development and IT (McKinsey, 2013). The system of shared service centers of multinational companies might bring the global business organization model to another level pushing the limits of productivity and quality, along with costs, making it preferable to outsourcing activities to specialized service providers. Tholons consulting firm has identified, since 2006, Central and Eastern European countries, especially Poland, Hungary and Romania, as being the main competitors to Asian markets in attracting captive processes and international service vendors due to their relatively skilled labor (Tholons, 2006).

Either way, the challenge for Romania is to improve labor qualification in IT services and stay among the most innovative locations, especially in Central and Eastern Europe, as a nearshore location.

\section{Labor cost and productivity as determinants of growing exports of ICT services in EU countries: Data, methodology and results}

In this section, we run an analysis that consists in a panel data regression where we explore the impact of labor cost and labor productivity on the exports of ITC services of each country in the sample. Our sample is composed of several EU member states because we want to see what has a more significant impact on export competitiveness out of the two indicators, in this common economic space and what conclusion we can draw for Romania.

The dependent variable is the domestic value added generated by each country in the panel, included in the exports of information technology and communication services. This value added is generated anywhere in the economy, not only in the ITC sector, but is included in the exports of ITC services. This data was collected from the TiVA Database, which is available up to 2015 (OECD, 2018). We chose the exported domestic value added instead of the total exports because this indicator excludes the foreign contribution to the exports, keeping only what is produced in the respective country.

The independent variables are the labor cost and productivity for ITC sector, the source of the data being the Eurostat database. The labor cost represents the average cost per employee, including the total remuneration in cash or in kind. The productivity is actually the wage adjusted labor productivity, obtained by dividing the value added by personnel costs and then adjusting the result by shared of paid employees in the total number of persons employed.

The panel contains 26 EU countries: EU28 except for France and Malta for which certain data was missing. Data has an annual frequency from 2008 to 2015.

Table 2: The impact of labor cost and productivity over the exported value added in ICT in EU countries

\begin{tabular}{ll}
\hline \hline Variable & Coefficient \\
\hline \hline Labor_cost & $150.68^{* * *}$ \\
\hline Productivity & $24.39^{* * *}$ \\
\hline R squared: & 0.9837 \\
\hline Adjusted $\boldsymbol{R}$-Squared & 0.9806 \\
\hline Prob $(\boldsymbol{F}$-statistic) & 0.0000 \\
\hline \multicolumn{1}{c}{$* * * * *$ and $*$ show the statistical significance at $\mathbf{1 \%}, \mathbf{5 \%}$ and $\mathbf{1 0 \%}$ respectively } \\
\hline \hline
\end{tabular}

Source: Author's calculation using EViews Student Lite

The results show a significant statistical influence of both indicators, labor cost and productivity, on the exported domestic value added in the ICT service sector in EU countries.

As expected, productivity has a positive influence on how much a country manages to increase the exports of services which are produced domestically.

On the other side, labor cost has an unexpected positive influence as well, fact that raises more issues for discussion. Firstly, we know that companies seek to reduce labor costs in order to increase competitiveness (Decramer et al. 2014) or relocate to different countries or regions to find labor at lower costs. Malgouyres and Mayer (2018) obtained insufficient evidence regarding the effects of a policy of cutting labor costs on the export performance of French companies. Secondly, increased work compensations have a positive impact on labor productivity. This serves to our result interpretation, having also the confirmation, through the other independent variable, that productivity raises exported value added. 
However, wages in the ICT sector have increased in the context of a low labor supply, inferior to the demand, because the higher education institutions were not able to provide enough specialists (Grigoraș et al, 2017).

Continuing the discussion, what actually matters for companies to improve their competitiveness is the total cost. Several other opportunities for cost reduction may come from lower taxes, cheaper utilities, cheaper real estate, cheaper equipment, etc. But cutting labor costs, especially in ICT where the quality of the output comes mainly from labor performance, might actually determine a loss of competitiveness.

\section{Concluding remarks}

Assessing Romania as a nearshore location for IT services for Western European clients, we find a promising growth of the IT sector. Romania has had a positive evolution in exports of ICT services, a generally positive evolution of FDI and an increase in employment.

However, comparing to the other countries in Central and Eastern Europe, Romania has the least specialized labor force in IT and limited possibilities of increasing its market volumes to a low number of trained people having a limited range of skills especially in high-end IT services. Although there is an increased global demand for IT services, the number of B.A. graduates in Romania has not kept up the pace.

The regression analysis, which tested the impact of the average labor cost per employee and labor productivity on exported value added that was domestically produced by EU countries in the ITC sector, aimed at drawing conclusions about the specificities of the export competitiveness of this particular economic space in which Romania is included. It showed that labor productivity has a significant positive influence on exports, but so does the labor cost. Usually lower labor costs stimulate the export performance, but in our case, it is the opposite. We cannot interpret the economic significance of this result isolated, instead we put this in parallel with the positive impact of productivity which is the value added generated by each employee related to unit labor costs. We know, from the data, that labor costs increased when productivity increased, but faster. Growing labor compensations stimulate productivity to a certain extent, or are given as rewards for performance, but there are other factors that influence productivity as well. So, a more correct interpretation would be that labor costs do not matter as much as productivity does for the export performance of these countries in ICT. This is supported by the market studies made by the cited consultancy firms which show that developed countries, including EU countries, are developing and exporting ICT services and products richer in value added compared to less developed countries. Romania has positioned its strategy in line with developing countries trying to attract investments which are suitable for low cost locations. But, at least as labor costs are considered, wages are growing and there is a continuous pressure as well.

Reaching the purpose of skill increase and diversification is a must because Central and Eastern European countries, based on the international demand, are positioning themselves as IT service providers which offer the best balance of cost and quality, following the objective of cost effectiveness rather than cost reduction.

The paper does not conclude that Romania is not a near-shore low-cost location anymore because costs are still relatively low, but Romania should reassess the balance between costs and productivity and should focus more on increasing skills, innovation and product development. There are undeniable opportunities for Romania to expand its activity in the IT sector due to a growing international demand either through the investments of multinational companies or local entrepreneurs or either through captive centers or outsourcing. The alternatives are numerous, but the main condition, that of specialized labor skills, especially in high value-added IT services, remains a challenge.

\section{References}

Abraham, F. (2001). Global and European labor costs (No. 102). Licos Discussion Paper.

Abramovsky, L., \& Griffith, R. (2006). Outsourcing and offshoring of business services: How important is ICT?. Journal of the European Economic Association, 4(2-3), 594-601.

Acemoglu, D., Aghion, P., Lelarge, C., Van Reenen, J., \& Zilibotti, F. (2007). Technology, Information, and the Decentralization of the Firm. The Quarterly Journal of Economics, 122(4), 1759-1799.

ANIS (2016), Software and IT Services in Romania 2016. [Online] Available: https://www.anis.ro/wpcontent/uploads/2016/05/Software-and-IT-Services-in-Romania-2016_General-Considerations-Excerpt.pdf (June 5, 2019)

ANIS (2018), Software \& IT Services in Romania Report, [Online] Available: https://www.itstudy.anis.ro/ (June 3, 2019)

Barrios, S., Mas, M., Navajas, E., \& Quesada, J. (2008). Mapping the ICT in EU regions: location, employment, factors of attractiveness and economic impact. 
Cette, G. (2014). Presidential Conference Does ICT remain a powerful engine of growth?. Revue d'économie politique, 124(4), 473-492.

Cette, G., Clerc, C., \& Bresson, L. (2015). Contribution of ICT Diffusion to Labour Productivity Growth: The United States, Canada, the Eurozone, and the United Kingdom, 1970-2013. International Productivity Monitor, (28), 81.

Decramer, S., Fuss, C., \& Konings, J. (2014). How do exporters react to changes in cost competitiveness?.

Draca, M., Sadun, R., \& Van Reenen, J. (2006). Productivity and ICT: A Review of the Evidence.

Dunning, J., \& Lundan, S. (1993). Multinational enterprise and the global economy, vol. Wokingham, England. European Commission, Eurostat Database, accessed on July $12^{\text {th }}, 2019$.

Harvey Nash and KPMG (2018), CIO Survey, [Online Available]: $<$ https://assets.kpmg/content/dam/kpmg/xx/pdf/2018/06/harvey-nash-kpmg-cio-survey-2018.pdf> (July 12, 2019).

Guan, J., \& Ma, N. (2003). Innovative capability and export performance of Chinese firms. Technovation, 23(9), 737747.

Guerrieri, P., \& Meliciani, V. (2004). International competitiveness in producer services. Available at SSRN 521445.

Kapeliushnikov, R. (2014). Labor productivity versus labor compensation: some simple arithmetic. VOPROSY ECONOMIKI, 3.

Kox, H. L., \& Rubalcaba, L. (2007). Analysing the contribution of business services to European economic growth.

KPMG, (2014), Romania as the destination for SSC and BPO. [Online] Available: http://www.outsourcingadvisors.ro/wp-content/uploads/2018/10/KPMG-Romania-as-the-destination-for-SSCsand-BPO.pdf (June 7, 2019)

Lasagni, A., \& Sforzi, F. (2007). Locational determinants of the ICT sector across Italy (No. 2007-EP03). Department of Economics, Parma University (Italy).

Malgouyres, C., \& Mayer, T. (2018). Exports and labor costs: evidence from a French policy. Review of World Economics, 154(3), 429-454.

McKinsey, (2013), Taking captive offshoring to the next level, McKinsey on Business Technology, number 32.

McKinsey \& Company, (2018), The rise of digital challengers: Perspective on Romania, [Online] Available: https://www.mckinsey.com/featured-insights/europe/the-rise-of-digital-challengers-perspective-on-romania, (July 13, 2019)

Meliciani, V., \& Savona, M. (2014). The determinants of regional specialisation in business services: agglomeration economies, vertical linkages and innovation. Journal of Economic Geography, 15(2), 387-416.

Miranda Levy, C. (2007). Information society and public ICT policies in the Caribbean: a review of advances and challenges, policy instruments and country experiences.

National Bank of Romania, (2017), Investițiile străine directe în România, [Online] Available: https://www.bnr.ro/PublicationDocuments.aspx?icid=9403, (August 6, 2019).

Grigoraș, V., Tănase, A., Leonte, A., (2017). Studiu al evoluțiilor sectorului IT\&C în România, National Bank of Romania, [Online] Available: https://www.bnr.ro/Studii,-analize,-puncte-de-vedere-4009.aspx, (July 5, 2019).

OECD (2018), Trade in Value Added Database, [Online] Available: <https://stats.oecd.org/Index.aspx?DataSetCode=TIVA_2018_C1\#>(July 12, 2019).

Porter, M.E. (1990), The Competitive Advantage of Nations, London: MacMillan.

Romanian National Institute of Statistics (2019), Education Statistics, [Online] Available: www.insse.ro, (August 9, 2019).

Saripalle, M. (2007). Export Competitiveness in the Indian auto-component industry: Does Low Wage Cost matter?. Madras School of Economics.

Sharpe, A. (2006). The Relationship between ICT investment and productivity in the Canadian economy: a review of the evidence. Centre for the Study of Living Standards= Centre d'étude des niveaux de vie.

Tholons (2006). Emergence of Centers of Excellence, Tholons Knowledgebase Article \#040601.

Van Ark, B., Inklaar, R., \& McGuckin, R. H. (2003). ICT and productivity in Europe and the United States Where do the differences come from?. CESifo Economic Studies, 49(3), 295-318. 